\title{
A phenomenological investigation of an English storyteller
}

\author{
Laely Nuriyah*, Maman Fathurrohman ${ }^{1}$ and Achmad Hufad ${ }^{2}$ \\ Universitas Sultan Ageng Tirtayasa, Indonesia ${ }^{1}$ \\ Universitas Pendidikan Indonesia, Indonesia ${ }^{2}$
}

\begin{abstract}
This research aimed to figure out what a storyteller's phenomenology was like. The method was phenomenological, and data was collected through interviews, questionnaires, documents, and data triangulation. According to the findings of this study, a storyteller can improve English language skills in four different areas. According to the findings of this study, students can improve their English language skills by telling stories. Several recommendations were made based on the previous conclusions. First, the researcher suggests that all of this research be continued by other researchers, particularly in digital storytelling with stories containing local content to help students understand and learn about Indonesian culture while also improving their ability to speak English. Second, the researcher hopes that the findings of this study will inspire students to learn more about storytelling.
\end{abstract}

\section{ARTICLE HISTORY}

Received November 27, 2021

Accepted December 17, 2021

Published December 31, 2021

\section{KEYWORDS:}

The storyteller, storytelling, descriptive phenomenology, English ability.

\section{Introduction}

Storytelling is a ubiquitous everyday practice among youth that seems inconsequential as the focus for the literacy education field, especially in English. And yet, as numerous critical literacy scholars have argued, when youth have the opportunity to explain and expand on the images, emotions and meaning of their lives, they may be recognized in new ways as people with complex social histories and insights about equity and justice (Agosto, 2013). Storytelling is a technique that students can use to learn English, particularly in speaking. It has a universal language function; the student can tell about a story that they have prepared in advance, such as a legend, folktale, or even their own story, because we are all unique narratives (Thornbury, 2005). It refers to the idea that each of us is a unique story that is constantly, unconsciously constructed by, through, and in us through our perceptions, feelings, thoughts, and actions; and, last but not least, our discourse, our spoken narration. Individuals gain a deeper understanding of the people with whom they interact through narrative, allowing them to recognize the uniqueness of their own and others' dispositions. (L. Russell, 2018). Inline, storytelling can be gained from our stories because we all have to tell about our lives. Students can use storytelling to tell the story of their lives by practicing in the classroom. Students can also practice conversation based on the dialogues in the story by using storytelling.

Storytelling also serves to understand others' experiences and observe how differences in people's values emerge. (L. Russell, 2018). The experience of the storyteller with storytelling is still a journey. It began with great apprehension, and to be honest, it was not entirely of her choosing. On the other hand, the storyteller was grateful to be challenged in this way, and she recognized the potential and power of storytelling every time she told a story. This shared, lived experience with her class brought them closer together in a profound and meaningful way, not only during the story, but also afterward (Tinckler, 2017). 
The storyteller with whom the researcher collaborates is frequently praised in her class for the entertainment value of her stories. Her storytelling goals, on the other hand, frequently align with critical literacy goals: to name what matters to her, to speculate about what is possible in her lives, to unravel contradictions, to make sense of the incomprehensible, to claim or question a point of view, to wonder, and to act. As a result, storytelling is a two-way interaction between the storyteller and the listeners or audience, in which the storyteller must employ storytelling techniques in order to receive feedback from the audience. The storytellers' building materials are words, sounds, and language patterns; their tools are voice projection, facial expression, and hand gestures; and their product is the creation of a shared human experience. As a result, storytelling is primarily concerned with bringing characters to life so that the storytellers and the audience can experience their emotions and thoughts. Characters can be brought to life by employing features such as diction, voice projection, intonation, gesture, facial expressions, and so on. (Y. B. Choo et al., 2020).

Storytelling is a social and cultural activity that focuses on telling and sharing stories ( Roig, et al., 2018). Sharing stories has always been one of the most common ways of passing down knowledge from generation to generation. People enjoy hearing stories, so they survive. Furthermore, stories are extremely important in our children's lives. We can say that every time they walk into their classroom, they feel compelled to tell stories because they are fantastic, entertaining, and fun. Engaging characters, narrative tension, and a unified point of view are all present in stories. These elements are present in man's earliest organized narratives, such as legends and folk tales, and are fundamental to all stories (Yahaya \& Shuhidan, 2020). There is a desire and a need to keep an eye out for bits of information that have the potential to become interesting stories. Curiosity is important, and asking critical questions about a story allows students to discover stories they can tell. Curiosity is a lowercase letter. It is at its weakest when people have no idea what the answer to a question is and when they are completely certain they know. When people think they have an idea but aren't sure, they are in the zone of maximum curiosity, which is where storytellers play. Loewenstein breaks down four ways of involuntarily inducing in humans in his paper "The Psychology of Curiosity." (1) "asking a question or presenting a puzzle; (2) "exposure to a sequence of events with an expected but unknown resolution; (3) "the violation of expectations that prompts a search for an explanation; (4) knowledge of someone else's possession of information." Storytellers have long known these principles who discovered them through practice and instinct (Storr, 2020).

All of the steps can be repeated to learn more about the storytelling method. It provides opportunities to expose the language while also giving the audience a second chance to figure out and confirm the meaning. If necessary, walk around the classroom to show the audience the pictures and repeat the text. According to Patton (2001), how people perceive, describe, feel about, judge, remember, make sense of, and talk about a phenomenon is determined by how they perceive, describe, feel about, judge, remember, make sense of, and talk about it with others. Meanwhile, the implied retention of "transcendence" in phenomenological perception within the phenomenological attitude (Husserl, 2006). It is also clear that such retention evidence is presupposed in empirical perception and that, in any case, a natural scientist who bases his or her work on empirical perception, and thus every philosopher who relies on natural knowledge, cannot suddenly become a hypercritic when dealing with phenomenology.

Based on the preceding statement, storytelling gives the storyteller the power to communicate with feeling and show the listener where they stand. And it demonstrates that someone's high-value experience will be a phenomenon. When we weave stories, one thread may come from our personal lives, another from our imagination, and yet another from our social experiences and how they affect us in some way (Simmons, 2007). When we use a story to elicit human emotions, we direct those emotions in a specific direction. Stories replicate the neurological effect of attention in our individual brains on a social level. What draws our attention is tended by society, and what draws society's attention is tended by society (Simmons, 2007). It means that we are testing whether we can create emotions or even behaviors by directing our attention to a past event. Objective thinking can distort our ability to analyze, understand, or predict human behavior because human behavior is subjective. Humans see and hear the world through eyes and ears that can only be in one place at a time. A subjective point of view that frames how a person feels about us, our idea, or our organization is represented by the collective past, present, and imagined future times and places.

To ensure that the study's previous is accurate, some other closely related studies relevant to the current research should be presented. According to Rosli and Idrus (2020), the students 
appeared to have a good understanding of conventional/traditional, digital, and cyber storytelling. Most of them had some experience with it or had participated in various storytelling activities. Students initially described storytelling in various ways, including retelling a story, bedtime stories, and gossip. Although Friday (2014) defined storytelling as a variety of things, including the story of your day, the story of your life, workplace gossip, and news horrors, this study discovered two types of storytelling: one is informal, narrated in a leisure mode for non-academic purposes, and the other is formal, a more classroom-based activity for academic purposes. Meanwhile, the researchers had conducted preliminary research for this project. It was held for two months, from December 11, 2020 to February 14 2021. The researcher conducted some interviews during this phase and documented the storyteller's journal. As a result, triangulation was used in this study to ensure that the findings were accurate. Several conclusions were drawn from the interviews and recorded in the storyteller's journal. The following findings were important to consider for the main study: 1). The participant's interest in reading a story, particularly a fairy tale that can teach her moral values, can be seen in the interview script. 2). in the other interview, she discussed how she learned to be a storyteller, how she used a variety of methods to comprehend the story, and how she did something unusual by chewing bubble gum to help her concentrate on her studies. This result reflected her learning style. 3). She demonstrated how she learned to be a storyteller in the other interview. She also demonstrated how she benefited from storytelling. 4). triangulation data: the interview scripts of the participant's friends. It revealed her personality as well as her English ability. The documents demonstrated the participant's many accomplishments at Al-Farhan Islamic Boarding School from Junior High to Senior High School, particularly her improvement in English. Storytelling helped her improve her English skills. Because of the benefits of storytelling in improving English skills and the benefit of phenomenological study in describing a phenomenon experienced by an individual, the writer intended to conduct this current study to descriptively reveal the process that Nurlya Rhomadhona goes through in order to become an excellent storyteller while also becoming skilled in English and phenomenon.

\section{Methodology}

The study employs phenomenological methodology to comprehend and describe the phenomenon and determine the essence of an English storyteller's encounter with it. "The basic phenomenology," according to Creswell, "is to reduce individual experiences with a phenomenon to a description of the universal essence" ( Creswell, 2012). The phenomenon is referred to as "the greatest storyteller experience" in this study. The goal is to distill the phenomenon's essence by reducing the participant's experiences of her educational achievement and use of storytelling in her educational environment to a description. Husserlian phenomenology is a type of descriptive phenomenology that holds that all experiences have one universal commonality or "correct interpretation." As a result, the analysis transforms into a quest for universal meaning. The researcher's ability to achieve "transcendental subjectivity" is thus central to descriptive phenomenology. It refers to the researcher's ongoing efforts to overcome personal knowledge, preconceptions, and biases, so that they do not influence or obstruct faithful or accurate recording of participant responses or data analysis (Husserl, 2006). High school students in grades 11 and 12 , both boys and girls, participated in this study.

As a result, the researcher is interested in capturing and recording the participant's experience as a storyteller about ways to improve English through storytelling, her attitude and motivation, her difficulties in developing English ability, and her ability to maintain storytelling, as well as investigating the moment of this lived experience through interviews, questionnaires, and documents. Moustakas' phenomenological data analysis procedure was applied to the data (1994). 


\section{Horizontalizing, or listing, all relevant expressions}

In the first step of data analysis, every statement was considered equal value. If some statements were irrelevant to the research phenomena, repetitive or overlapping, the researcher deleted these statements. The remaining parts of the data consisted of horizons (Husserl, 2006). A horizon is described as the phenomenon's textural meaning or constituent parts.

\section{Reduction of experiences to the invariant constituents}

In this step, the horizons were clustered into themes. The translated data were split into meaning units so that each of horizons had only one meaning.

\section{Thematic clustering to create core themes}

In this step, the researchers clustered the invariant constituents, which are the horizons, and defined them as "the core themes of the experience" ( Moustakas, 1994).

\section{Comparison of multiple data sources to validate the invariant constituents}

The themes derived from the participant's experiences reported in the interview were compared to the researcher's observation field notes, interviews and literature to ensure accuracy and clear representation across the data sources.

\section{Crafting of individual textural descriptions of participant}

The textural description is a narrative that explains participants' perceptions of the phenomenon. For this step, the researchers created textural descriptions defined as the participant's experiences using excerpts from their interviews verbatim. The researcher explained the meaning units in a narrative format to understand what the participant experienced.

\section{Crafting of individual structural descriptions of participant}

This step is based on the textural descriptions and imaginative variation. In the imaginative variation process, the researcher imagined how an experience occurred and created the structures. The researcher created a textural description for this single participant and incorporated it into a structure that explained how the experience occurred.

\section{Construction of composite structural descriptions}

The composite structural description was a combination of five individual structural descriptions that underlined the shared meaning units and reflected the participant's experience as a whole. The common features of the experience accounted for the essence of the experience of an English storyteller.

\section{Results and Discussion}

According to the findings and data presented above, how the storyteller developed her English storytelling ability was an ally in the dual-language environment. According to Duman \& Göcen (2015), the most effective and successful method to apply to enhance the pupils' acquisition of the language is to use digital storytelling or storytelling technique. It's also seen as the best way to turn literary genres into a vivid mental image that helps students build and enrich their vocabulary bank while also stimulating their senses, such as hearing and sight.

The kind of language she heard and was exposed to at home and in the immediate environment, such as at Islamic Boarding School, may have influenced the storyteller's learning differences (proficiency and attitudes). The results of L2 teaching to participants as storytellers from the following backgrounds may differ significantly, for example, the storytellers living in dual-language families, the storytellers influenced by a supportive environment, natural settings where L2 is used for communication either as an official language or as a community language, and educational settings where L2 is used as a means of instruction in the classroom.

As a result, the storyteller realized that storytelling could help her improve her public speaking skills. She had tried a variety of methods to improve her English skills, including reading aloud. She had always put it into practice as much as she could. She learned a lot from her collective experiences in order to constantly improve and develop her English ability to be better than before. Oral storytelling is an effective teaching and learning tool because it engages students' mental imagery and imagination in the story (Choo, Y. B et al., 2020). When a storyteller 
has good speaking skills, it shows that she can give her English storytelling power. She was well aware that her retelling of a story could inspire a large number of people in her immediate vicinity.

According to Rosli and Idrus (2020), the students appeared to have a good understanding of conventional/traditional, digital, and cyber storytelling. Most of them had some experience with it or had participated in various storytelling activities. Students initially described storytelling in a variety of ways, including retelling a story, bedtime stories, and gossip. The researcher discovered that some of the theories elucidated above were related to the findings about the ways storyteller develops her English storytelling ability, and she gained a stronger passion for English.

\section{The Storyteller's Positive Attitudes}

The storyteller had very positive attitudes toward English and English storytelling because she had supportive parents and an environment that encouraged her to improve her English skills. Attitude, like personality trait, is a hypothetical construct that must be inferred from measurable responses because it is inaccessible to direct observation. Given the construct's nature, these responses must reflect positive or negative evaluations of the attitude object (Azjen, 2005). Whether she had verbal or nonverbal responses to the object, institution, or event in question, the storyteller had shown her positive attitude in this study. These responses can be cognitive in nature, reflecting perceptions of the object or beliefs about its likely characteristics; effective in nature, reflecting the person's judgments and feelings; and conative in nature, indicating how a person acts or would act in relation to the object. There were many reasons to expect that measured attitudes toward storytelling would be related to English ability, as evidenced by the aforementioned findings. Many aspects of the storyteller's upbringing clearly influenced his or her attitudes. The researcher discovered reinforcement for the storyteller's English ability based on her friend at Al-Farhan Islamic Boarding School who knew her and the expert judgment affirmation. According to the findings, storytellers must have a positive attitude toward English and storytelling in English.

\section{The Storyteller's Motivation}

According to the questionnaire and the storyteller's response, the storyteller had higher motivation and desire to learn English, and her orientation index toward English was the highest with a percentage of 100 percent. It can be concluded that the storyteller had a positive attitude toward English as well as a strong desire to learn the language. Furthermore, the storyteller had to use both motivating and fascinating stories. According to the storyteller, students who identify as stronger storytellers develop stronger storytelling skills in identifying appropriate story ideas and themes. The different types of documentary stories told and identified by the students allow for a strong visual conceptualization of the story, which improves their understanding of documentary storytelling at the same time (Yahaya \& Shuhidan, 2020). The findings that showed the motivational intensity and the storyteller's personal style profile elucidated these theories. Meanwhile, digital storytelling or storytelling strategy simplifies teaching and language acquisition, maintains students' enthusiasm for learning, focuses their attention, and increases motivation (Tabieh et al., 2021). According to the theory, the storyteller had a high level of motivation. She had a strong interest in English ever since she entered an English competition, such as an English speech or an English storytelling competition. She also thought the teachers and her English story were very motivating. She was also very motivated to weave her dream about her English achievement from that point forward. As a result, the storyteller's attitudes and motivation were significant because they reflected an active involvement on his or her part in the entire process of learning English. As the researcher's expert judgment improved, she found support for her storyteller English ability from a friend at Al-Farhan Islamic Boarding School who knew her well.

\section{The Storyteller's Difficulties in Developing English Ability}

The researchers were able to understand better how storytellers interpret the storytelling text. She had to memorize as much as she could and then read it aloud as many times as she could. These were the most straightforward ways for her to understand the storytelling text comprehensively. According to Yigit (2020), students in multilingual classes reflect their cultural environment, and stories allow us to learn about them. Because stories are typically told by people who have lived through the events and said the words. Without even realizing it, people find it easier to present themselves in stories. In order to overcome the challenges and constraints of English storytelling, 
the storyteller had some strategies and a style. After several years of instruction, the learner's beliefs about L2 as a storyteller appear to be very stable, but her affective states may vary depending on the teacher's personality traits, the type of tasks performed in the classroom, and the results she obtained.

Furthermore, storytelling creates engaging and intellectually rich learning environments through creativity, various forms of literacy, and a variety of modalities (Nassiem, 2018). The findings that convinced the storyteller of constraint factors and her ways to solve the problem based on her style and strategy were in line with the theory above. She was well-behaved and interested in English, completing all academic tasks and overcoming her English learning difficulties.

The storyteller's English ability was found to be reinforced by her friend at Al-Farhan Islamic Boarding School, who knew her well. According to the excerpt from the interview above, the storyteller's school life was extremely memorable. She had so many accomplishments that she inspired other students at Al-Farhan Islamic Boarding School. The storyteller had improved her English storytelling ability with a lot of achievements in English, as evidenced by her friend's reinforcement. It also persuaded me that college life was so memorable. She was able to exist and always attempted to solve all of her problems in English.

\section{The Ways Storyteller Maintains English Ability}

Because she believed that speaking English was a habit, the storyteller tried to maintain her English ability with her classmates in college. Whenever she met up with them and communicated with them, she tried to speak English. She realized she needed to be able to communicate in English in order to manage her English. Digital storytelling is a powerful tool for integrating instructional messages with learning activities to create more engaging and exciting learning environments, as stated in these statements. It's a method for establishing a constructivist learning atmosphere (Nassiem, 2018). Based on the theories mentioned above, the researcher discovered that they were related to the findings, implying that she attempted to apply the moral value from her English story always to struggle and maintain her English ability. She understood that each story contained different lessons that we could apply in our daily lives. In short, the findings about how the storyteller maintained her storytelling ability revealed personal and general factors, with the storyteller learning habit being the most important.

The evidence that storytelling provided many benefits to the storyteller is used to support this claim. It was in line with the expert's conclusion based on his research. According to this research, there are ten advantages to using storytelling as an educational tool: 1). In order to improve and develop all four primary language arts skills, storytelling is a powerful and effective tool (reading, writing, listening, and speaking). 2) When information (both concepts and facts) is presented in the form of a story, it is remembered better and for longer. 3). Storytelling is an interdisciplinary, cross-curricular teaching tool that is powerful and effective. 4). Storytelling encourages students to learn by motivating them to tell their own stories. Students' attention and learning are heightened when stories are told, and they are motivated to pursue related studies. 5). Storytelling helps students develop self-confidence and self-esteem. 6). Storytelling engages and develops imagination and creativity skills more effectively than any other single classroom activity. 7). Storytelling entertains and engages the audience. Storytelling fosters empathy and a sense of belonging. 9). Storytelling improves problem-solving and analytical skills. 10) Storytelling strengthens ties to one's community and heritage (Haven, 2000).

Nurlya Rhomadhona, my participant as a storyteller, had a good English ability and how phenomenon her life experience as a storyteller is, based on the testimony of participant friends and the expert judgment of the lecturer. Storytelling provided her with a diverse range of language and cultural experience.

\section{Conclusion}

The focus of this research would be on the description of some lived experience; it was the great storyteller's experience and with the researcher aiming to elicit the maximum amount of information about the topic at hand. The researcher's purpose here was to present a model design for use by both novice and experienced researcher that can provide a much-needed and to date lacking guide for approaches by which to gain better understanding of and elicit richer material from the storyteller about her English ability.

The method of phenomenology, which involved describing the phenomenon of a story teller who was able to improve English language skills, limited this study. Sharing stories, as the storyteller had done, was an important part of her literacy development because stories could 
help her to (1) broaden her knowledge and understanding of other races and beliefs, particularly Indonesian folklore, (2) expose her to a wider range of story-sharing experiences, (3) stimulate her imagination, (4) expand her vocabulary and provide her with good models of use, enunciation, and pronunciation, and (5) expand her vocabulary and provide her with good models of use, enunciation, and pronunciation. (5) Encourage her to pay attention, concentrate, and follow event-structured material; (6) Challenge her assumptions and introduce new ideas in a nonthreatening manner; (7) Develop her thinking skills; (8) Nurture and encourage a sense of humor; and (9) Increase her appreciation of literature and reinforce cultural values, particularly those found in Indonesian folklore.

Several recommendations were made based on the previous conclusions. First, the researcher suggests that all of this research be continued by other researchers, particularly in digital storytelling with stories containing local content to help students understand and learn about Indonesian culture while also improving their ability to speak English. Second, the researcher hopes that the findings of this study will inspire students to learn more about storytelling.

The storyteller grew up in a variety of social environments in Islamic Boarding School, where she could learn about various topics and form opinions about the consequences of her actions, the normative expectations of important others, and the obstacles that might prevent her from carrying out a behavior. All of these things were required to develop English skills, and they were similar to how a storyteller developed her English skills.

\section{References}

Agosto, D. (2013). If I had three wishes: The educational and social/emotional benefits of oral storytelling. Storytelling, Self, Society, 9, 53-76.

Ajzen, I. (2005). Attitudes, personality \& behavior ( $2^{\text {nd }}$ ed). New York: Open university press.

Choo, Y. B., Abdullah, T., \& Nawi, A. M. (2020). Digital storytelling vs. Oral storytelling: An analysis of the art of telling stories now and then. Universal Journal of Educational Research, 8(5 A), 46-50. https://doi.org/10.13189/ujer.2020.081907

Cresswell, W, J. (2012). Qualitative Inquiry \& Research Design among Five Approaches (4th ed). Lincoln: University of Nebraska. Sage publications Inc. Syafrizal, S, Masrupi MASRUPI, I. M. (2019). The impact of experiential learning method and vocabulary mastery toward indonesian students' reading comprehension through animation video. Journal for the $\begin{array}{lllll}\text { Education of } \quad \text { Gifted } & \text { Young }\end{array}$ https://doi.org/10.17478/jegys.531412

Duman, B., \& Göcen, G. (2015). The effect of the digital storytelling method on pre-service teachers' creative writing skills. Anthropologist, 2O(1-2), 215-222.

Friday, M. J. (2014). How storytelling inspires children to learn English. from http://www.edutopia.org/https://www.edutopia.org/blog/storytelling-inspires-childrenlearnenglish-matthew-Friday.

Haven, K. F. (2000). Super Simple Storytelling: a Can-Do Guide foe Every Classroom Everyday. Greenwood Publishing Group, Inc.

Husserl, E. (2006). The Basic Problems of Phenomenology. Netherlands. Springer.

Moustakas, C. (1994). Phenomenological Research Methods. Thousand Oaks, CA: Sage.

Nassim, S. (2018). Digital Storytelling: An Active Learning Tool For Improving Students' Language Skills. PUPIL: International Journal of Teaching, Education and Learning, 4(1), 14-29. https://doi.org/10.20319/pijtel.2018.21.1429

Patton, Q. M. (2002). Qualitative Research and Evaluation Method (3rd ed). Sage Publication.

Roig, A., R. Pires de Sá, and G. S. Cornelio. (2018). "Future Story Chasers: An Experience with Co Creation of Fiction in the Classroom Through a Collaborative Storytelling Game." Catalan Journal of Communication and Cultural Studies 10 (2): 279-289. https://doi:10.1386/cjcs.10.2.279_1

Rosli, M. R., \& Idrus, F. (2020). Cybernated Storytelling: Revitalising Storytelling Activities For Secondary School Students. Teaching English with Technology, 17(3), 19-34.

Russell, L. (2018). Relational Storytelling and Critical Reflections on Difference. Journal of Communication Pedagogy, Vol. 1(1) 52-57. https://doi.org/10.31446/jcp.2018.10

Simmons, A. (2007). Whoever Tells the Best Story Wins: How to Use Your Own Stories to Communicate with Power and Impact. New York: Amacom.

Storr, W. (2020). The Science of Storytelling: Why Stories Make Us Human, and How to Tell Them Better. UK, London: Harper Collins Publisher. 
Tabieh, A. A. S., Al-Hileh, M. M., Abu Afifa, H. M. J., \& Abuzagha, H. Y. (2021). The effect of using digital storytelling on developing active listening and creative thinking skills. European Journal of Educational Research, 10(1), 13-21. https://doi.org/10.12973/eujer.10.1.13

Thornbury, S. (2005). How to Teach Speaking. New York: Pearson educational ltd. Longman.

Tinkler. R. (2017). Connecting Storytelling and Social Wellness: A Case for Holistic Storytelling in the Elementary Classroom. http://sciencedirect.com

Yahaya, W. A. W., \& Shuhidan, M.S . (2020). Documentary Storytelling Techniques: Mapping Strategies among Film Students. Universiti Teknologi MARA (UiTM), 600-RMI/DANA 5/3/ARAS(90/2016). http://doi.org/10.24191/ajue.v16i3.10273

Yigit, E.O. (2020). Digital storytelling experiences of social studies pre-service teachers. International Journal of Technology in Education (IJTE), 3(2), 70-81. 